\title{
PENGARUH BAHAN AJAR HANDOUT TERHADAP PENINGKATAN KETERAMPILAN PROSES PESERTA DIDIK KELAS VII PADA MATERI EKOSISTEM DI SMP NEGERI 3 BATAM TAHUN PELAJARAN 2012/2013
}

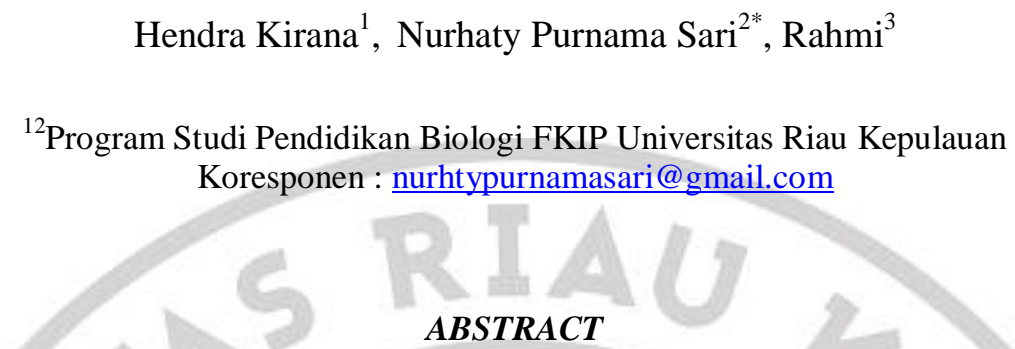

This research has been carried out in SMP Negeri 3 Batam is located on the street Kartini II Sekupang, Batam. While time research has been carried out in the second half Academic Year 2012/2013, from March to May of 2013. This study aims to prove the influence of handout materials to increase the skills of the students of class VII on ecosystem material in SMP Negeri 3 Batam Academic Year 2012/2013. Handout is a concise study materials are sourced from some of the literature relevant to the basic competencies and subject matter that is taught to students given by teachers to students to achieve learning goals. While the process skills of learners is the ability to collect information, manage information and communicate the results of using information to achieve learning objectives both on cognitive aspects or psychomotor aspects. Research using quasi-experimental methods. Affordable population is all students of class VII with the target population VII ${ }_{1}$ class as a class experiment with a treatment using learning materials and classroom handouts $\mathrm{VII}_{4}$ as classroom control by providing a treatment study using conventional materials. Cluster sampling using random sampling techniques. Research data is data science learning outcomes Biological processes in the form of skills, which is obtained using the test results to learn the instrument objective test (multiple choice). Data were analyzed with descriptive statistical analysis techniques and inferential statistical analysis using the $t$ test of the parties at significant level $(\alpha)=$.0.05 . Based on the analysis of the calculation results obtained descriptive study of students from the class experiment with a mean value of 83.6 and a mean value of 80 control classes. While the calculation of inferential analysis of testing hypotheses derived $t_{\text {count }} 2,081$ and the value $t_{\text {table }} 2,018$. Thus the value of $t$ greater than $t_{\text {table }}$ which means a hypothetical zero $(\mathrm{Ho})$ is rejected and the alternative hypothesis $(\mathrm{Ha})$ is accepted. Overall it can be concluded the research, analysis of the calculation of descriptive and inferential analysis proves that there are significant handout materials to increase the skills of the students of class VII on ecosystem material in SMP Negeri 3 Batam Academic Year 2012/2013.

Keywords: Handout; Process Skills; Ecosystems.

\section{PENDAHULUAN}

Berdasarkan Standar Isi untuk satuan pendidikan dasar dan menengah yang diterbitkan Badan Nasional Standar Pendidikan (BNSP) Tahun 2006, materi pembelajaran ekosistem merupakan materi wajib bagi peserta didik kelas VII yang berpedoman dengan kurikulum. Materi ekosistem memuat konsep-konsep dasar tentang memahami saling ketergantungan dalam ekosistem, menentukan ekosistem dan saling hubungan antara komponen ekosistem, mengidentifikasi pentingnya keanekaragaman makhluk hidup dalam pelestarian ekosistem, memprediksi pengaruh kepadatan populasi manusia terhadap 
Hendra Kirana, Nurhaty Purnama Sari, Rahmi : Pengaruh bahan ajar handout...

lingkungan, mengaplikasikan peran manusia dalam pengelolaan lingkungan untuk mengatasi pencemaran dan kerusakan lingkungan yang harus dikuasai peserta didik.

Keterampilan proses peserta didik perlu dikembangkan dan ditingkatkan karena masih banyak pendidik mengunakan bahan ajar yang konvensional. Bentuk-bentuk bahan ajar konvensional seperti buku-buku teks jumlah lembar halamannya banyak terlihat tebal membuat peserta didik malas membaca dan belajar. Sehingga, pada akhirnya, yang harus menjadi korban adalah peserta didik. Peserta didik merasa bosan mengikuti proses pembelajaran, sehingga proses pembelajaran menjadi tidak efisien dan tidak efektif yang berakibat belum optimalnya hasil belajar keterampilan proses peserta didik.

Bahan ajar yang disampaikan oleh pendidik sering kali tidak berasal dari satu buku, tetapi dari beberapa sumber buku. Tidak semua peserta didik memiliki semua sumber buku wajib dan referensi yang diperlukan dalam proses pembelajaran. Untuk peserta didik yang memiliki kemampuan menerima secara lisan kurang kuat perlu adanya alat bantu dalam menguasai materi pembelajaran. Peserta didik perlu alat bantu dalam menguasai bahan yang disajikan dengan jelas dan sistematis, terutama untuk peserta didik yang memiliki kemampuan menerima secara lisan kurang kuat. Untuk pendidik yang mempunyai kebiasaan mengajar dengan cepat atau kurang sistematis perlu diimbangi dengan bahan ajar yang dikembangkan sendiri. Namun, pendidik tahu bahwa pembelajaran yang menarik, efektif dan efisien membutuhkan bahan ajar yang tidak cukup hanya seperti buku yang banyak atau yang LKS banyak.

Tujuan dalam penelitian ini yaitu: membuktikan pengaruh bahan ajar handout terhadap peningkatan keterampilan proses peserta didik kelas VII pada materi ekosistem di SMP Negeri 3 Batam Tahun Pelajaran 2012/2013. Penelitian ini diharapkan dapat memberikan manfaat berupa informasi secara tertulis maupun sebagai referensi mengenai bahan ajar handout dan keterampilan proses serta menambah wawasan dan pengetahuan tentang bahan ajar handout untuk meningkatkan keterampilan proses peserta didik dalam proses pembelajaran khususnya pembelajaran IPA Biologi.

\section{METODOLOGI PENELITIAN}

Penelitian ini telah dilaksanakan di SMP Negeri 3 Batam yang beralamat dijalan Kartini II Sekupang, Batam. Sedangkan waktu penelitian telah dilaksanakan pada semester II TP 2012/2013, dari bulan Maret sampai dengan bulan Mei tahun 2013. Secara 
operasional penelitian ini bertujuan untuk meningkatkan hasil belajar keterampilan proses mengunakan bahan ajar handout. Secara rinci tujuan operasional penelitian ini adalah untuk membuktikan pengaruh bahan ajar handout terhadap peningkatan keterampilan proses peserta didik pada materi ekosistem di SMP Negeri 3 Batam TP 2012/2013. Variabel dalam penelitian ini yaitu variabel terikat (Y) dan variabel bebas (X). Variabel terikat yang menjadi fokus dalam penelitian ini adalah hasil belajar IPA yaitu keterampilan proses $(\mathrm{Y})$, sedangkan variabel bebas sebagai perlakuan yang diberikan dalam penelitian ini adalah bahan ajar $(\mathrm{X})$ yaitu bahan ajar handout $\left(\mathrm{X}_{1}\right)$ yang merupakan perlakuan pada kelas eksperimen dan bahan ajar konvensional seperti buku paket $\left(\mathrm{X}_{2}\right)$ yang merupakan perlakuan pada kelas kontrol.

Metode yang digunakan dalam penelitian ini adalah metode eksperimen semu (Quasi Experiment) dengan Populasi terjangkau adalah seluruh peserta didik kelas VII dengan populasi sasaran yaitu kelas $\mathrm{VII}_{1}$ sebagai kelas eksperimen dengan memberikan perlakuan berupa pembelajaran mengunakan bahan ajar handout dan kelas $\mathrm{VII}_{4}$ sebagai kelas kontrol dengan memberikan perlakuan berupa pembelajaran mengunakan bahan ajar konvensional. Jumlah sampel penelitian untuk kelas eksperimen dan kelas kontrol masingmasing berjumlah 30 peserta didik. Pengambilan sampel mengunakan teknik Cluster Random Sampling. Desain penelitian yang digunakan adalah two-group pottest only design, merupakan desain eksperimen yang memiliki dua kelompok data yaitu data posttest kelompok eksperimen dan kelompok kontrol. Data yang dikumpulkan berupa data hasil belajar keterampilan proses dengan mengunakan tes hasil belajar dalam bentuk soal objektif (pilihan ganda) yang dilaksanakan setelah kegiatan pembelajaran dilaksanakan.

Sebelum instrumen digunakan, terlebih dahulu peneliti melakukan kalibrasi instrumen tes untuk mendapatkan karakteristik tes yang baik dengan cara memvaliditas dan mereliabilitas tes tersebut. Validitas tes dilakukan dengan cara validitas internal (validitas konten dan kontruksi) dikonsultasikan dengan tenaga ahli sebanyak 3 orang. Setelah dilakukan validitas internal dilanjutkan validitas secara empiris mengunakan point biserial correlation $\left(\mathrm{r}_{p b i s}\right)$ dengan tujuan setiap butir soal memiliki kesahihan secara empirik. Sedangan reliabilitas tes dilakukan dengan perhitungan koefisien reliabilitas mengunakan metode KR-20 (Kuder Ricardson-20) dengan tujuan setiap butir soal yang disusun memiliki keterandalan secara empirik. 
Hendra Kirana, Nurhaty Purnama Sari, Rahmi : Pengaruh bahan ajar handout...

Kalibrasi instrumen tes dilaksanakan di SMP Negeri 20 Batam yang beralamat di Jalan Gajah Mada Tiban Koperasi Sekupang, Batam. Kalibrasi instrumen tes menggunakan 25 butir soal dalam bentuk tes objektif pada materi pembelajaran ekosistem. Pengambilan populasi dan sampel data untuk kalibrasi instrumen tes objektif dilaksanakan dengan tehnik cluster random sampling. Kalibrasi instrumen tes objektif diperoleh data dari kelas 7.1 yang berjumlah 30 peserta didik. Dari pengujian validitas tes baik secara internal maupun secara empiris mengunakan point biserial correlation $\left(\mathrm{r}_{p b i s}\right)$ dengan taraf signifikan $(\alpha)=0.05$ menunjukan 25 butir soal dinyatakan valid. Sedangkan hasil reliabilitas tes dengan mengunakan metode KR-20 (Kuder Ricardson-20) dengan taraf signifikan $(\alpha)=0.05$ diperoleh nilai koefisien reliabilitas instrumen tes objektif sebesar 0,851 yang diinterpretasikan dengan nilai pada tabel $r$ menunjukan instrumen tes hasil belajar yang disusun memiliki tingkat reliabilitas yang sangat tinggi.

Data penelitian dianalisis dengan statistik deskriptif dan inferensial. Analisis statistik deskriptif secara umum digunakan untuk menyajikan data dalam distribusi frekuensi yang divisualisasikan dalam bentuk histogram. Analisis statistik inferensial dilakukan untuk pengujian hipotesis dan generalisasi hasil penelitian. Sebelum melakukan pengujian hipotesis terlebih dahulu dilakukan uji prasyarat, berupa uji normalitas dan uji homogenitas. Uji normalitas mengunakan uji liliefors dan uji homogenitas mengunakan uji barlett.

Pengujian hipotesis dilakukan dengan mengunakan uji t satu pihak dengan rumus separated varians untuk membuktikan pengaruh bahan ajar handout terhadap peningkatan keterampilan proses. Pengolahan data dilakukan menggunakan program microsoft excel.

\section{HASIL DAN PEMBAHASAN}

Hasil penelitian dan pembahasan diuraikan dari hasil analisis statistik deskriptif dan statistik inferensial. Hasil analisis statistik deskriptif dipaparkan pada deskripsi data dari kelas eksperimen maupun kelas kontrol. Sedangkan hasil analisis statistik inferensial dipaparkan pada uji hipotesis dengan mengunakan uji t. Teknik analisis yang digunakan untuk mendeskripsikan data adalah ukuran pemusatan data (tendensi sentral) dan ukuran penyebaran data (tendensi penyebaran). Hasil belajar keterampilan Proses sebagai suatu pencapaian peserta didik terhadap kompetensi pemahaman mengenai materi ekosistem diperoleh berdasarkan proses pembelajaran. Keterampilan proses diukur mengunakan tes 
hasil belajar berbentuk tes pilihan ganda dengan skor dikatomi. Rentang nilai teoritis hasil belajar keterampilan proses yaitu 0-100. Rekapitulasi perhitungan statistik deskriptif secara keseluruhan sampel disajikan pada Tabel 1.

Tabel 1. Rekapitulasi data statistik keseluruhan data sampel penelitian.

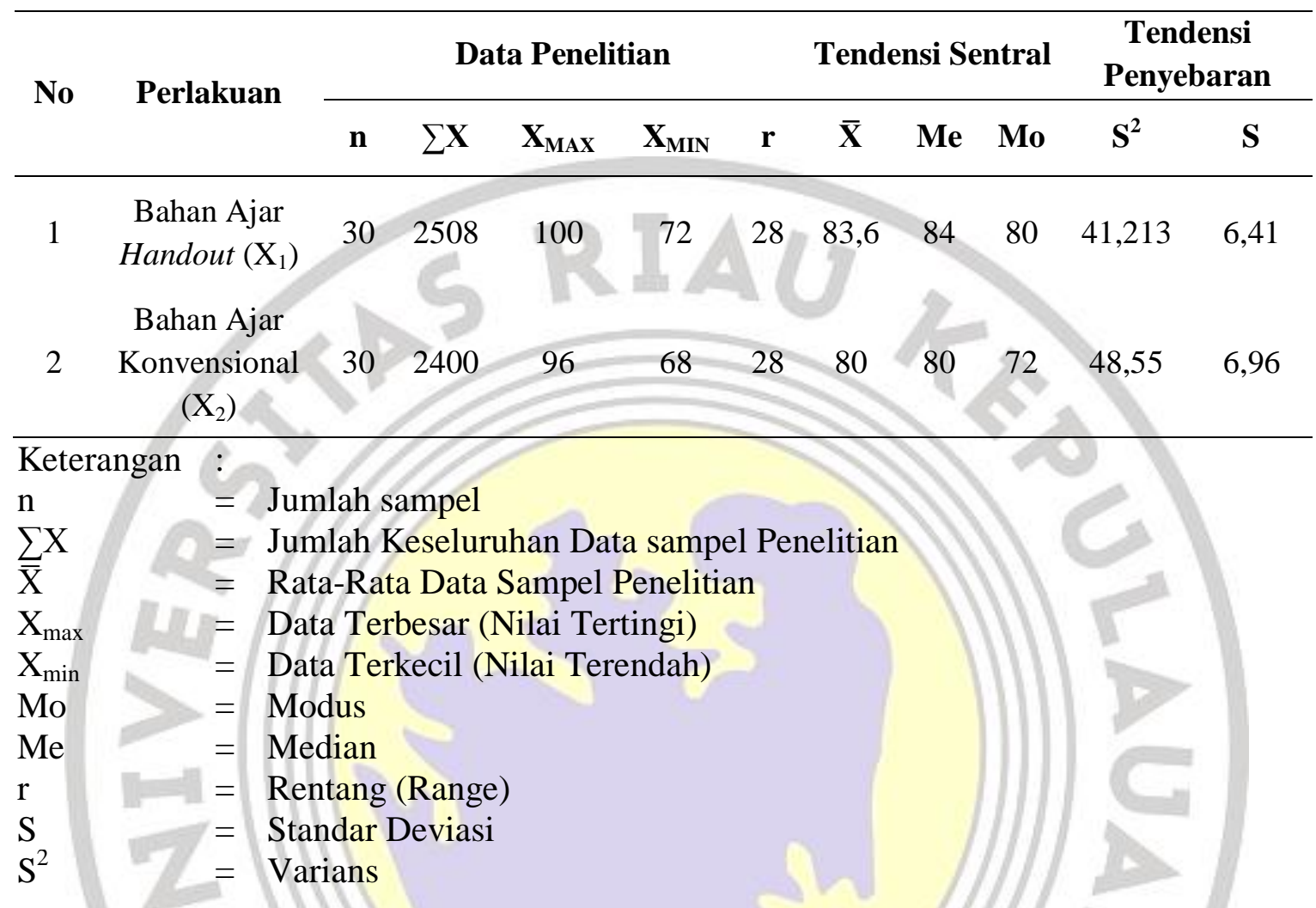

Secara umum terlihat bahwa keseluruhan peserta didik kelas VII SMP Negari 3 Batam yang mengikuti proses pembelajaran mengunakan bahan ajar handout sebanyak 30 siswa diperoleh nilai tertinggi 100 , nilai terendah 72 , rata-rata sampel penelitian 83,6 , median 84 dan modus 80 . Sedangkan hasil belajar keterampilan proses mengunakan bahan ajar konvensional menunjukan data dengan jumlah sampel penelitian sebanyak 30 peserta didik diperoleh nilai tertinggi 96 , nilai terendah 68 , rata-rata sampel penelitian 80 , median 80 dan modus 72, dengan demikian hasil belajar keterampilan proses mengunakan bahan ajar handout lebih baik dibandingakn mengunakan bahan ajar konvensional. Secara umum distribusi frekuensi data hasil penelitian tiap-tiap kelompok perlakuan dapat dilihat pada Gambar 1. 
Hendra Kirana, Nurhaty Purnama Sari, Rahmi : Pengaruh bahan ajar handout...

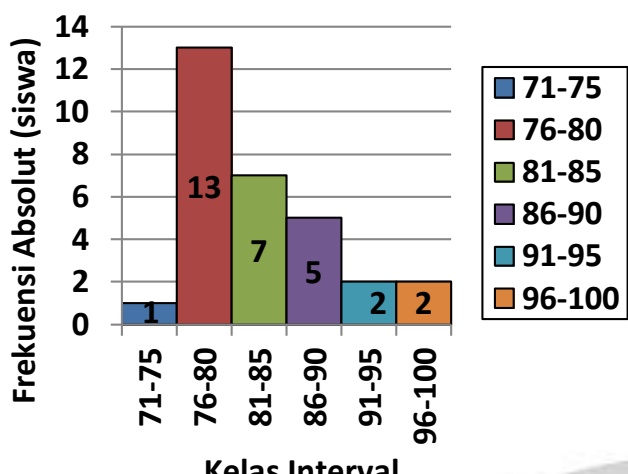

Kelas Eksperimen $\left(\mathrm{X}_{1}\right)$

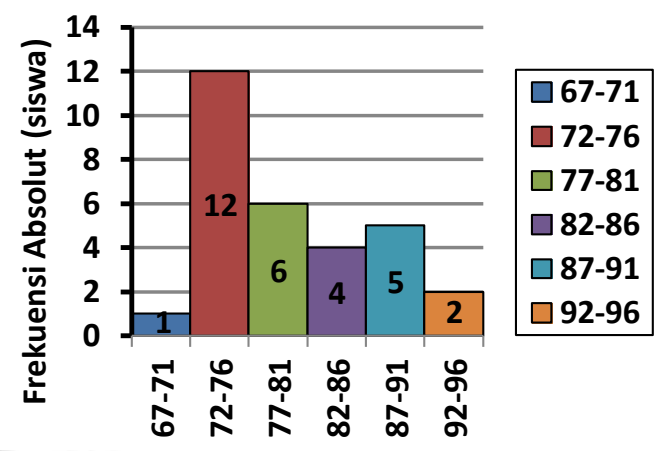

Kelas Interval

Kelas Kontrol $\left(\mathrm{X}_{2}\right)$

Gambar. 1 Histogram Hasil Belajar Keterampilan Proses Tiap-Tiap Kelompok Perlakuan

Berdasarkan hasil perhitungan yang telah divisualisasikan ke dalam histogram pada gambar 1 , terlihat bahwa dari 6 kelas interval peserta didik pada kelas eksperimen $\left(\mathrm{X}_{1}\right)$, peserta didik yang terbanyak di rentang nilai 76-80 terdapat 13 siswa dan pada rentang nilai tertinggi 96-100 terdapat 2 siswa serta nilai terendah yang diperoleh peserta didik pada rentang nilai 71-75 adalah sebanyak 1 siswa. Sedangkan pada kelas kontrol $\left(\mathrm{X}_{2}\right)$, peserta didik yang terbanyak di rentang nilai 72-76 terdapat 12 siswa dan pada rentang nilai tertinggi 92-96 terdapat 2 siswa serta nilai terendah yang diperoleh peserta didik pada rentang nilai 67-71 adalah sebanyak 1 siswa. Dari hasil perhitungan dari kelas eksperimen dan kelas kontrol diperoleh data jenis-jenis keteramapilan proses yang ditabulasikan pada Tabel 2.

Tabel 2. Rekapitulasi Data Jenis-Jenis Keterampilan Proses Kelas $\mathrm{X}_{1}$ dan $\mathrm{X}_{2}$

\begin{tabular}{ccccccc}
\hline No & $\begin{array}{c}\text { Jenis Keterampilan } \\
\text { Proses }\end{array}$ & $\begin{array}{c}\mathrm{KP} \mathrm{X}_{1} \\
(\%)\end{array}$ & $\begin{array}{c}\mathrm{KP} \mathrm{X}_{2} \\
(\%)\end{array}$ & $\begin{array}{c}\mathrm{KP} \\
\left(\mathrm{X}_{1}-\mathrm{X}_{2}\right)\end{array}$ & $\begin{array}{c}\text { Hasil KP } \\
(\%)\end{array}$ & Keterangan KP \\
\hline 1 & Observasi & 73,3 & 67,5 & 5,8 & 17,4 & Meningkat \\
2 & Klasifikasi & 94,2 & 85,0 & 9,2 & 27,3 & Meningkat \\
3 & Komunikasi & 94,4 & 90,0 & 4,4 & 13,2 & Meningkat \\
4 & Pengukuran & 100,0 & 96,7 & 3,3 & 9,9 & Meningkat \\
5 & Prediksi & 82,2 & 78,9 & 3,3 & 9,9 & Meningkat \\
6 & Inferensi & 63,3 & 53,3 & 10,0 & 29,8 & Meningkat \\
7 & Identifikasi variabel & 71,7 & 76,7 & $-5,0$ & $-14,9$ & Tidak \\
8 & Interpretasi & 85,0 & 82,5 & 2,5 & 7,4 & Meningkat \\
\hline
\end{tabular}


Keterangan:

KP : Keterampilan Proses

$\mathrm{KP} \mathrm{X}_{1}$ : Keterampilan Proses Kelas Eksperimen

$\mathrm{KP}_{2}$ : Keterampilan Proses Kelas Kontrol

Berdasarkan hasil perhitungan pada tabel 2 terlihat bahwa jenis keterampilan proses yang persentasinya paling tinggi pada kelas eksperimen $\left(\mathrm{X}_{1}\right)$ adalah pengukuran yaitu $100 \%$, dan jenis keterampilan proses yang paling rendah adalah inferensi yaitu 63,3\%. Sedangkan pada kelas kontrol $\left(\mathrm{X}_{2}\right)$ terlihat bahwa jenis keterampilan proses yang persentasinya paling tinggi adalah pengukuran yaitu $96,7 \%$, dan jenis keterampilan proses yang paling rendah adalah inferensi yaitu 53,3\%. Secara keseluruhan hasil perhitungan menunjukan terjadi peningkatan 7 dari 8 jenis keterampilan proses yang telah di uji. Jenis keterampilan proses yang paling tinggi peningkatanya yaitu inferensi sebesar $29,8 \%$ dan jenis keterampilan proses yang paling rendah peningkatanya yaitu interpretasi sebesar $7,4 \%$, sedangankan pada jenis keterampilan proses identifikasi variabel tidak terjadi peningkatan.

Analisis statistik inferensial untuk melakukan uji terhadap hipotesis penelitian yang diajukan. Sebelum melakukan uji hipotesis, data hasil penelitian harus berdistribusi normal dan populasinya homogen. Prasyarat uji normalitas dilakukan dengan menggunakan uji lilifors dan uji homogenitas populasi menggunakan uji Barlett. Uji normalitas dilakukan untuk melihat normal atau tidaknya sebaran data yang akan dianalisis dari setiap kelompok perlakuan penelitian. Uji normalitas dilakukan dengan menggunakan uji liliefors pada taraf signifikansi $(\alpha)=0,05$.

Berdasarkan hasil perhitungan uji normalitas menggunakan uji Liliefors, untuk kelompok perlakuan pembelajaran dengan menggunakan bahan ajar $\left(\mathrm{X}_{1}\right)$ diperoleh nilai $\mathrm{L}_{\text {hitung }}$ sebesar 0,146 dan untuk kelompok perlakuan pembelajaran dengan menggunakan bahan ajar konvensional $\left(\mathrm{X}_{2}\right)$ diperoleh nilai $\mathrm{L}_{\text {hitung }}$ sebesar 0,149 , sedangkan nilai kritis $\mathrm{L}_{\text {tabel }}$ pada taraf signifikan $(\alpha)=0,05$ sebesar 0,161 , karena nilai $\mathrm{L}_{\text {hitung }}$ untuk setiap kelompok perlakuan lebih kecil dibandingkan nilai kritis $\mathrm{L}_{\text {tabel }}$, maka hipotesis nol (Ho) diterima, berarti data dari kedua kelompok perlakuan berdistribusi normal dan uji dapat dilanjutkan untuk melihat homogenitas asal populasi kelompok data.

Uji homogenitas populasi dilakukan dengan menggunakan uji Barlett pada taraf signifikan $(\alpha)=0,05$. Hasil perhitungan homogenitas diperopeh nilai chi-kuadrat hitung 
Hendra Kirana, Nurhaty Purnama Sari, Rahmi : Pengaruh bahan ajar handout...

$\left(\chi 2_{\text {hitung }}\right)$ sebesar 0,19 sedangkan nilai chi-kuadrat tabel $\left(\chi 2_{\text {tabel }}\right)$ pada taraf signifikan $\alpha=$ 0,05 . Sebesar $=3,84$. Karena nilai chi-kuadrat hitung $\left(\chi 2_{\text {hitung }}\right)$ lebih kecil dari chi-kuadrat tabel ( $\left.\chi 2_{\text {tabel }}\right)$ maka pengujian menerima hipotesis nol (Ho), sehingga disimpulkan bahwa data dari kedua kelompok perlakuan bersifat homogen dan berasal dari populasi yang sama, dengan demikian perlakuan penelitian telah memenuhi persyaratan analisis untuk menguji hipotesis.

Uji Hipotesis dilakukan dengan teknik analisis statistik inferensial bertujuan mengkaji, menaksir dan mengambil kesimpulan berdasarkan data yang diperoleh dari sampel untuk mengambarkan karakteristik atau ciri dari suatu populasi. Teknik analisis statistik inferensial dilakukan dengan mengunakan uji t karena data homogen, berdistribusi normal dan kelas yang digunakan sebanyak 2 kelas yaitu kelas eksperimen dan kontrol serta hubungan variabel bebas dan terikat bersifat parsial serta standar deviasi belum diketahui. Uji $t$ dalam penelitian ini bertujuan untuk membuktikan terdapat atau tidaknya pengaruh bahan ajar handout dalam meningkatan keterampilan proses peserta didik kelas VII pada materi ekosistem di SMP Negeri 3 Batam Tahun Pelajaran 2012/2013 dari perbadan hasil belajar dari kedua kelompok perlakuan.

Pengujian hipotesis dilakukan untuk melihat adanya pengaruh perlakuan dari kedua kelas (kelompok perlakuan) dengan cara membandingkan rerata kedua kelompok data mengunakan uji $\mathrm{t}$ dengan taraf signifikan $(\alpha)=0.05$. Rekapitulasi hasil perhitungan uji $\mathrm{t}$ antar kelompok perlakuan penelitian pada taraf signifikansi $(\alpha)=0,05$. Berdasarkan uji $\mathrm{t}$ satu pihak diperoleh nilai $t_{\text {hitung }}$ dari perbandingan rerata antar kelompok perlakuan sebesar 2,081 sedang nilai $t_{\text {tabel }}$ uji $t$ satu pihak pada taraf signifikan $(\alpha=0,05)$ dengan jumlah sampel setiap kelompok perlakuan (n) sebanyak 30 peserta didik diperoleh sebesar 2,018. Karena nilai $t_{\text {hitung }}$ lebih besar dari $t_{\text {tabel }}$ maka pengujian menolak hipotesis nol (Ho). Hasil penelitian menerima hasil hipotesis alternatif $(\mathrm{Ha})$, sehingga terdapatnya pengaruh bahan ajar handout terhadap peningkatan keterampilan proses peserta didik kelas VII pada materi ekosistem di SMP Negeri 3 Batam TP 2012/2013.

Mulyatiningsih (2012) menyatakan dalam penelitian eksperimen, pengaruh memberi makna terdapat perubahan atau peningkatan sebagai akibat adanya perlakuan maka perlakuan tersebut dinyatakan memberi pengaruh. Pengaruh bisa dibuktikan dari hasil kelompok yang diberi perlakuan lebih tinggi dari kelompok yang tidak diberi perlakuan atau ada peningkatan sebelum dan sesudah perlakuan. Dari pernyataan 
Mulyatiningsih (2012) dan hasil analisis secara deskriptif serta hasil analisis secara inferensial (uji hipotesis) membuktikan terdapat pengaruh bahan ajar handout terhadap peningkatan keterampilan proses peserta didik kelas VII SMP Negeri 3 Batam pada materi ekosistem TP 2012/2013. Hasil penelitian membuktikan bahwa peserta didik yang mengikuti pembelajaran dengan menggunakan bahan ajar handout pencapaian hasil belajar berupa keterampilan prosesnya lebih baik dari peserta didik yang mengikuti pembelajaran mengunakan bahan ajar konvensional, ini berarti pembelajaran dengan bahan ajar handout memberikan pengaruh dalam meningkatkan hasil belajar berupa keterampilan proses peserta didik.

Dalam penelitian ini bahan ajar handout mampu meningkatkan keterampilan proses peserta didik pada pembelajaran IPA Biologi karena peserta didik akan cepat mengerti karena inti sari pada materi telah terkonsep dalam pikiran peserta didik, yang kemudian mengisi dan mengembangkan dalam proses pembelajaran hal ini sesuai pernyataan Prastowo (2012) menyatakan dalam proses pembelajaran handout memiliki tujuan yaitu untuk pengingat karena materi dalam handout dapat digunakan sebagai pengingat yang bisa dimanfaatkan peserta didik untuk mempelajari materi sesuai urutan yang dianjurkan dan telah terangkuman.

Selain itu juga di dalam handout terdapat gambar-gambar materi pembelajaran ekosistem yang menstimulus kemempuan visual peserta didik/mengunakan indra penglihatan. Munadi (2013) menyatakan gambar merupakan media visual yang penting sebab dapat menganti kata verbal, mengkonkritkan yang abstrak dan mengatasi pengamatan manusia.

\section{KESIMPULAN}

Berdasarkan hasil pengujian hipotesis dan pembahasan secara keseluruhan, diperoleh kesimpulan dari penelitian ini yaitu: secara umum terdapat pengaruh bahan ajar handout terhadap peningkatan keterampilan proses peserta didik kelas VII pada materi ekosistem di SMP Negeri 3 Batam Tahun Pelajaran 2012/2013. Hasil analisis statistik deskriptif bahwa hasil belajar keterampilan proses mengunakan bahan ajar handout $\left(\mathrm{X}_{1}\right)$ dengan nilai rerata $\left(\mu \mathrm{x}_{1}\right)$ sebesar 83,6 lebih baik dari hasil belajar berupa keterampilan proses dengan mengunakan bahan ajar konvensional $\left(\mathrm{X}_{2}\right)$ denga rerata nilai $\left(\mu \mathrm{x}_{2}\right)$ sebesar 80. Hasil analisis statistik inferensial membuktikan nilai $t_{\text {hitung }}$ sebesar 2,081 lebih besar 
Hendra Kirana, Nurhaty Purnama Sari, Rahmi : Pengaruh bahan ajar handout...

dari nilai $t_{\text {tabel }} 2,018$. Karena nilai $t_{\text {hitung }}$ lebih besar dari $t_{\text {tabel }}$ maka pengujian menerima hasil hipotesis alternatif (Ha), sehingga terdapat pengaruh bahan ajar handout terhadap peningkatan keterampilan proses peserta didik kelas VII pada materi ekosistem di SMP Negeri 3 Batam TP 2012/2013. Hasil belajar IPA Biologi peserta didik menunjukan bahwa peserta didik yang mengikuti pembelajaran dengan bahan ajar handout lebih tinggi nilainya dibandingan dengan peserta didik yang mengikuti pembelajaran dengan bahan ajar konvensional yang telah teruji dan terbukti kebenaranya. Sehingga pemanfaatan bahan ajar handout mampu meningkatkan hasil belajar keterampilan proses.

Berdasarkan hasil penelitian dalam upaya meningkatan proses pembelajaran yang pada akhirnya meningkatkan hasil belajar berupa keterampilan proses pendidik disarankan untuk dapat memilih, mengembangkan, dan menerapkan bahan ajar dalam kegiatan pembelajaran salah satunya adalah bahan ajar handout dan juga mencari sumber-sumber belajar, informasi-informasi baru yang relevan dengan materi yang akan diajarkan, sehingga pendidik tidak mengalami hambatan dalam kegiatan pembelajaran dan pendidik disarankan untuk selalu meningkatkan kompetensi keahlian dalam ilmu pengetahuan untuk meningkatkan hasil belajar berupa keterampilan proses peserta didik.

\section{REFERENSI}

Belawati, Tian, dkk. 2003. Pengembangan Bahan Ajar. Pusat Penerbitan Universitas Terbuka. Jakarta.

Kirana, H. 2013. Pengaruh Bahan Ajar Handout Terhadap Peningkatan Keterampilan Proses Peserta Didik Kelas VII pada Materi Ekosistem di SMP Negeri 3 Batam Tahun Pelajaran 2012/2013. [Skripsi] Program Studi Pendidikan Biologi, FKIPUNRIKA Batam.

Munadi, Y. 2013. Media Pembelajaran Sebuah Pendekatan Baru. Referensi. Jakarta.

Prastowo, A. 2012. Panduan Kreatif Membuat Bahan Ajar Inovatif. Diva Press. Jogjakarta. Pribadi, B. A. 2011. Model ASSURE Untuk Mendesain Pembelajaran Sukses. Dian Rakyat. Jakarta.

Purba, E. C. 2012. Pengaruh Model Quantum Teaching Mengunakan Media Handout Terhadap Peningkatan Hasil Belajar Siswa Pada Materi Pokok Usaha dan Energi di Kelas XI SMA Negeri 2 Sidikalang Tahun Pelajaran 2012/2013. Skripsi FKIP UNIMED. Medan. Tidak Diterbitkan. http://digilib. unimed.ac.id lindex.php. [21 Februari 2013]. 
Siregar, S. 2013. Statistik Parametrik untuk Penelitian Kuantitatif Dilengkapi dengan Perhitungan Manual dan Aplikasi SPPS Versi 17. Jakarta: Bumi Aksara.

Susanti, E. 2010. Pengaruh Penggunaan Handout dalam Model Pembelajaran Kooperatif Tipe Kancing Gemerincing terhadap Hasil Belajar Biologi Siswa Kelas VII SMP Negeri 7 Padang Tahun Pelajaran 2009/2010. Skripsi FKIP UNP. Tidak Diterbitkan. http://biolib.Pandani. web.id/2011/02/eva-susanti-pengaruhpenggunaan-hand.html. [01 April 2013].

Syahza, A dan Henny Indrawati. 2007. Peningkatan Hasil Belajar Mata Kuliah Manajemen Agribisnis Melalui Pemberian Handout pada Mahasiswa Jurusan Manajemen Fakultas Ekonomi Universitas Riau. Jurnal Sosiohumaniora Vol; 9, No 3, November 2007, Lembaga Penelitian Universitas Padjadjaran, Bandung. http://almasdi.unri.ac.id [01 April 2013].

Trianto. 2010. Model Pembelajaran Terpadu. PT Bumi Aksara. Jakara.

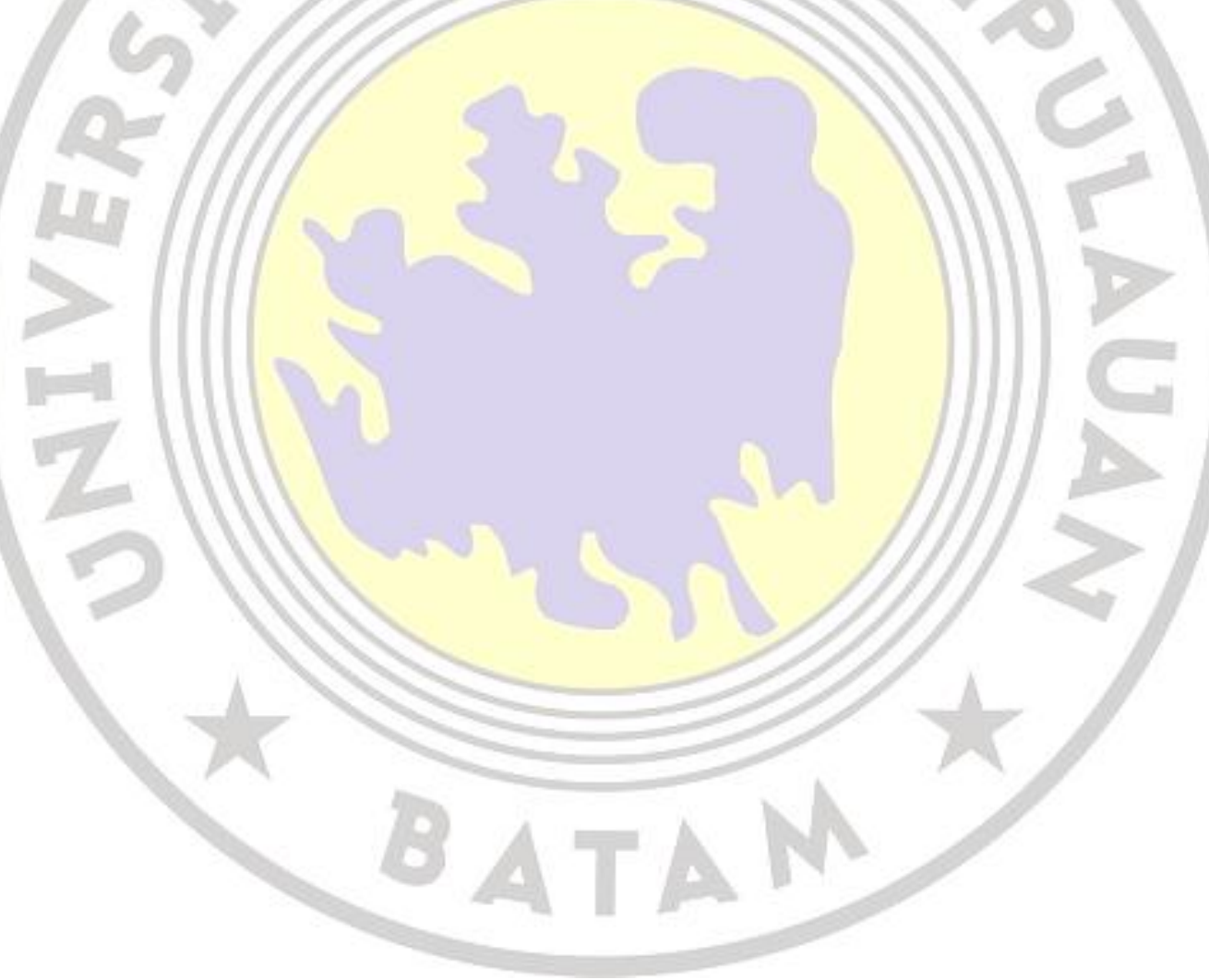

